\title{
Contextual Approach Animated Video in Science Material for Grade Fourth Elementary School Students
}

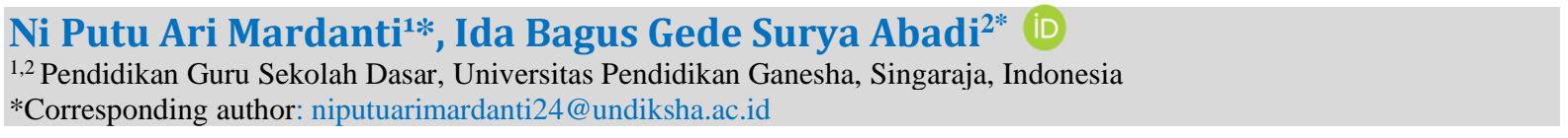

\section{Abstrak}

Kurangnya bahan pendukung pembelajaran dan perlunya pengembangan media untuk membantu guru dalam menjelaskan materi pembelajaran. Pembelajaran hanya berpatokan pada buku tema, maka dari itu perlu dikembangkan video animasi daring berpendekatan kontekstual pada muatan materi IPA. Penelitian ini bertujuan mengembangan media pembelajaran video animasi berpendekatan kontekstual pada muatan materi IPA. Jenis penelitian ini adalah pengembangan dengan model penelitian pengembangan model ADDIE. Metode pengumpulan data yang digunakan adalah metode kuesioner atau angket, metode wawancara dan metode pencatatan dokumen. Teknik analisis data yang digunakan adalah teknik analisis kualitatif dan teknik analisis kuantitatif. Subjek penelitian ini adalah pengembangan media video animasi. Hasil dari penelitian ini yakni deskripsi rancang bangun pengembangan media video animasi daring berpendekatan kontekstual berupa hasil dokumentasi pengembangan produk dan hasil validasi menurut review ahli isi mata pelajaran diperoleh nilai sebesar 100\% kualifikasi sangat baik, review ahli desain pembelajaran diperoleh nilai 97\% dengan kualifikasi sangat baik, review ahli media pembelajaran diperoleh nilai 97\% dengan kualifikasi sangat baik, review ahli perorangan diperoleh sebesar 97,3\% dengan kualifikasi sangat baik dan review ahli kelompok kecil dengan perolehan 98,67\% dengan kualifikasi sangat baik. Maka dapat disimpulkan pengembangan media video animasi daring berpendekatan kontekstual sangat baik digunakan dalam materi IPA kelas IV di Sekolah Dasar. Implikasi penelitian yaitu media video animasi berpendekatan kontekstual dapat membantu siswa dalam belajar.

Kata kunci: Video, Animasi, Kontekstual, IPA

\section{Abstract}

Lack of learning support materials and the need for media development to assist teachers in explaining learning materials. Learning is only based on the theme book. Therefore, it is necessary to develop animated videos with a contextual approach to the content of science material. This study aims to develop an animated video learning media with a contextual approach to the content of science material. This type of research is the development of the ADDIE model development research model. Data collection methods used are questionnaires or questionnaires, interview methods, and document recording methods. Data analysis techniques used are qualitative analysis techniques and quantitative analysis techniques. The subject of this research is the development of animated video media. The results of this study are a description of the design and development of animated video media with a contextual approach in the form of product development documentation and validation according to subject content experts' reviews which obtained a score of $100 \%$ very good qualification, a review of learning design experts obtained a score of $97 \%$ with very good qualifications. Learning media expert reviews obtained a score of $97 \%$ with very good qualifications, and media expert reviews were obtained by $97.3 \%$ with very good qualifications and group expert reviews with $98.67 \%$ gains with very good qualifications. So it can be said as the development of animated video media with a contextual approach is very well used in fourth-grade science material in elementary schools. The research implication is that contextual approach animation video media can help students in learning.

Keywords: Videos, Animation, Contextual, natural science

\begin{tabular}{lll}
\hline History: & & Publisher: Undiksha Press \\
Received & : March 19, 2021 & Licensed: This work is licensed under \\
Revised & : March 21, 2021 & a Creative Commons Attribution 3.0 License \\
Accepted & : June 10, 2021 & CCC O) O \\
Published & : July 25, 2021 & SA
\end{tabular}

\section{Introduction}

Education is a right for everyone, and education does not look at age, distance, and place (Marhayani, 2016; Wu \& Wu, 2020). Education can be pursued and explored anywhere, such as the current example of current education. In the Covid-19 pandemic situation, learning activities are no longer carried out in schools but at their respective homes online according to policy (Goldschmidt, 2020; Patricia, 2020; Sahu, 2020). Changes in the 
learning system from outside the network (offline) to online (online) have a significant impact, especially for teachers who are the spearhead of educational change (Chou, 2013; Rigianti, 2020). The influence during the current pandemic has led to global changes in terms of economy, social, culture, health, including changes in the world of education (Hincal \& Alsaadi, 2021; Kolta \& Ghonimy, 2020). The world of education is currently experiencing significant changes, such as the use of design techniques that can be used in learning today (Goldschmidt, 2020; Mpungose, 2021). All activities cannot be carried out, as usual, many people do activities at home. Given that the risk of spreading it is still very high and the development of the virus is speedy, learning can only be done by applying the Health protocol (Kadafi et al., 2021; Shodiq \& Zainiyati, 2020).

Teachers in grade IV elementary schools also feel this; based on the results of observations and interviews, it is known that teachers find it challenging to explain learning materials, especially on science content in online learning activities. Natural Science (IPA) material content in elementary schools is compulsory material content for students to learn. Science examines living and inanimate objects and everything about the symptoms that exist in nature (Komala, 2016; Mulyantini et al., 2019; Trianawati, 2019). The problem encountered is that learning outcomes that have not yet reached the maximum must be addressed because understanding the material in class IV can affect learning outcomes at the next level. Each individual has an essential difference in terms of interests, talents, and knowledge in science. Therefore, in one class, there are various characteristics of students' knowledge, there are students who excel in the science field, and there are also students with low science knowledge competence.

Students who have less knowledge are learning difficulties and require good, planned, and integrated handling efforts to improve students' science knowledge competence (Gürsoy, 2021; Setiawan et al., 2017). In addition, the next problem is through asynchronous assignment activities. The learning process is only based on the material in thematic books or other sourcebooks so that students do not understand the material and expand the knowledge possessed by students. Teachers find it difficult to explain learning materials to students via WhatsApp because of the limited interaction between teachers and students (Padli \& Rusdi, 2020; Yunitasari \& Hanifah, 2020). The impact on the decline in learning interest and student knowledge competence. Apart from being limited in space and time, the use of less innovative and varied media is also another cause (Jogezai et al., 2021; Linda et al., 2018).

Based on these problems, one solution that can be given is the development of learning media in the form of animated video media as a form of using technology in online learning activities. Animated video media positively impacts students as a means and intermediary for learning to understand learning materials in an easy and fun way (Megawati \& Utami, 2020; Rahayuningsih, 2020). This animated video media contains information in text, images, and audiovisuals packaged in a file (Fadhli, 2015; Lin \& Li, 2018). The final result of animated video media is made in $\mathrm{Html}$ and $\mathrm{CD}$ formats to facilitate the use of media either through mobile phones or other digital equipment such as computers or laptops in online learning (Rubini et al., 2018; Yulando et al., 2019). In addition, this media can also be used in offline learning by utilizing LCD projectors facilitated by schools.

Another advantage of this contextual approach is that animated video media can overcome the limitations of space and time so that this media can be accessed anywhere and repeatedly played (Andini et al., 2018; Noviyanto et al., 2015). In addition, this animated video media can be used by students individually or in groups, and this animated video media can also clarify abstract things for students, especially in learning materials of various styles (Kartika et al., 2019; Van Alten et al., 2020). Animated video media is different from previous research, namely animated video media which developed science material content in learning various styles accompanied by a contextual learning approach with real examples 
that are close to students' daily lives so that it can motivate and facilitate students to understand the material (Kühl, 2021; Tapingkae et al., 2020). This is supported by research that has been done previously. Learning media can make it easier for students to learn, attract students' attention to study, and improve student learning outcomes (Amali et al., 2020; Satyawan, 2018). Other research also states that the results are that animated video media can attract students' attention to study, help clarify the material so that students can learn quickly, and can increase students' cognitive knowledge (Saripudin et al., 2018; Endang Saripudin et al., 2018).

In the development of animated video media in general, the developed video media still does not integrate learning models or learning strategies, so students are less motivated to learn. Meanwhile, this animated video media product was developed with a contextual approach and is equipped with examples that are often encountered by students in everyday life so that learning becomes more exciting and easier for students to understand. Thus, the purpose of this research is to develop an animated video learning media with a contextual approach that can increase students' interest.

\section{Methods}

This type of research is development research $(R \& D)$, wherein developing animated video media is carried out by applying the ADDIE model. The ADDIE model has systematic steps to overcome learning problems related to learning resources according to the needs and characteristics of student learning (Alnajdi, 2018; Widiyasanti et al., 2018). ADDIE consists of five systematic steps, namely analysis, design, development, implementation, evaluation, which are easy to understand and implement in the research product development process (Hidayatulloh, 2019; Rubini et al., 2018). This research was conducted in elementary schools. The subject of this research is animated video media developed with a contextual learning approach that is packed with real examples of styles in students' daily lives.

The data collection method in this development research used the questionnaire method. The questionnaire method was used when analyzing student needs, product trials on test subjects, namely subject content experts, instructional design experts, learning media experts, individual trials, and small group trials on students. The experts consist of 1 subject expert, a lecturer at Ganesha Education University who teaches science courses, one learning design expert, and 1 learning media expert, namely a Ganesha Education University lecturer who has educational technology qualifications. Individual trials were conducted on 3 fourthgrade students and small group trials involving 9 fourth-grade students at SD Negeri 2 Blahbatuh. The questionnaire was given using a closed questionnaire. An open questionnaire consists of 12 statement items in the subject content expert questionnaire consisting of 4 aspects, namely aspects of material structure, material content, grammar, and evaluation, 8 statement items in the instructional design expert questionnaire consisting of 3 aspects, namely objectives, strategies and evaluations, 15 statement items in the learning media expert questionnaire consisting of 3 aspects, namely appearance, technical and media, and 11 statements in the individual test questionnaire consisting of 4 aspects, namely display, material, technical and evaluation. The grid for the assessment instrument for animated video media with a contextual approach is as follows Table 1.

Table 1. Expert Instrument Grid of Lesson Content

\begin{tabular}{ll}
\hline No $\quad$ Aspect & \multicolumn{1}{c}{ Indicator } \\
\hline 1. Material structure & a. Conformity with basic competence \\
& b. Compliance with indicators \\
& c. Fit for purpose \\
\hline
\end{tabular}




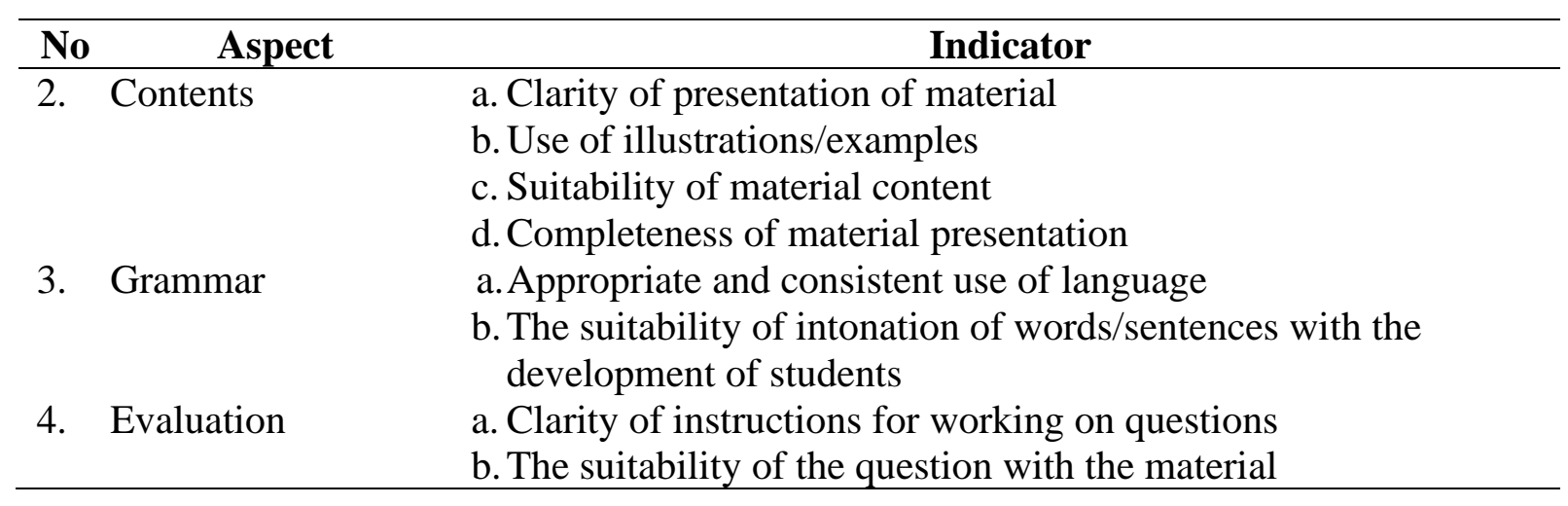

Table 2. Instructional Design Expert Instrument Grid

\begin{tabular}{lll}
\hline \multicolumn{1}{c}{ No } & Aspect & \\
\hline 1. Goal & a. Clarity of learning objectives \\
2. Strategy & a. Conformity of delivery strategy \\
& & b. Delivery strategy accuracy \\
& c. Presentation of material in the media motivates students \\
3. Evaluation & a. Clarity of instructions for working on questions \\
& & b. Suitability of questions with learning objectives \\
\hline
\end{tabular}

Table 3. Grid of Learning Media Expert Assessment Instruments

\begin{tabular}{ll}
\hline No & Aspect \\
\hline 1. Appearance & a. Design \\
& b. Text \\
& c. Picture \\
& d. Color \\
2. Technical & a. Ease of use \\
& b. The use of media can motivate students \\
3. Media & a. Contents \\
& b. Easy to understand material \\
\hline
\end{tabular}

The data analysis method used in this development research is the quantitative descriptive analysis method. The quantitative descriptive method is a way to process data systematically into numbers or percentages to get general conclusions (Agung, 2014). In this study, quantitative descriptive analysis was used to process the data obtained through a questionnaire in the form of scores. To provide meaning in decision-making, a determination or reference for conversion of the level of achievement is used on a scale of 5 .

\section{Results and Discussion Results}

The results of the research on the development of animated video media with a contextual approach to the content of science material regarding various styles of grade IV in elementary schools will discuss two main things, namely describing the design of animated video media with a contextual approach and describing the validity results of animated video media with a contextual approach. The design of animated video media with a contextual approach uses the ADDIE development model, which has five stages. The first stage is the analysis stage, at this stage is carried out (1) analysis of student characteristics and learning 
problems through filling out student needs analysis questionnaires filled out by students, (2) analysis of learning content through interviews with teachers, and (3) analysis of facilities and environment through observation activities to the research location. The second stage is the design stage. The concept design is carried out at this stage, such as designing storyboards, storylines, flowcharts, sound effects, voice actors (narrator), designing animated characters in the video to be made, and making media covers. In this development stage, the activities carried out combine concepts made previously at the design stage and develop into a product that can be implemented.

The fourth stage is the product implementation stage. At this stage, the activities carried out were (1) testing the validity of the animated video media product with a contextual approach based on the aspect of the subject content tested by subject content experts, (2) testing the validity of the animated video media product with a contextual approach based on the aspect of the learning media tested by a learning media expert. (3) test the validity of the animated video media product with a contextual approach based on the aspects of learning design experts tested by learning design experts. (4) conducting individual tests with 3 students who have differences in learning achievement, and (5) conducting small group tests with 9 students who have differences in learning achievement. At this stage, the aim is to determine the feasibility and quality of the animated video media with a developed contextual approach. The last stage is the evaluation stage. This stage is an evaluation of the data that has been collected at the implementation stage. Evaluations are carried out to measure or assess learning products, including expert validation, individual trials, and small group trials. The results of the development of animated videos are presented in Figure 1.

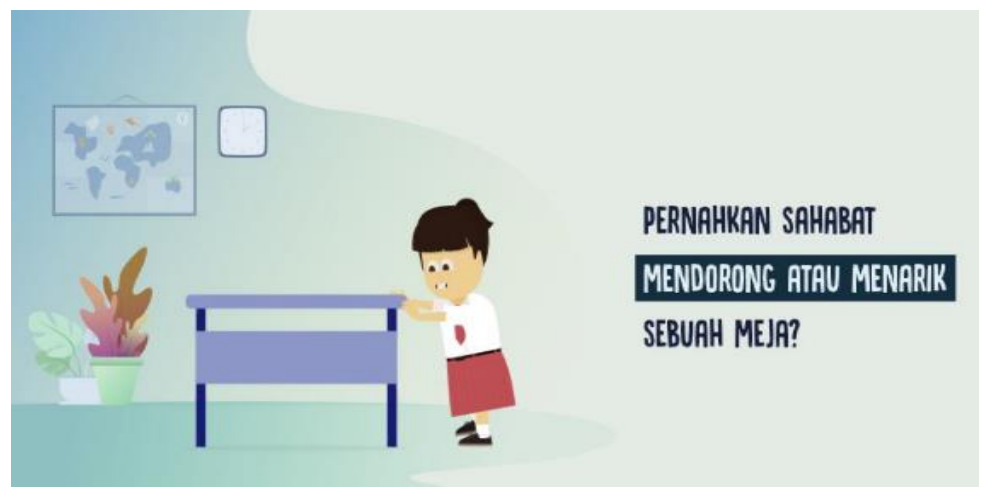

Figure 1. Developed animation video

The results of the validity of the animated video media with a contextual approach based on the results of subject content expert reviews, instructional media expert reviews, learning design experts reviews, individual test reviews, and small group test reviews will be presented in the form of a table as follows.

Table 4. Product Validity Test Results

\begin{tabular}{cccc}
\hline No & Achievement Level & Validity Results & Information \\
\hline 1. & Subject Content Expert Test & $100 \%$ & Very good, no need to revise \\
2. & Learning Media Expert Test & $97 \%$ & Very good, no need to revise \\
3. & Learning Design Expert Test & $97 \%$ & Very good, no need to revise \\
4. & Individual Trial & $97,3 \%$ & Very good, no need to revise \\
5. & Small Group Trial & $98,67 \%$ & Very good, no need to revise \\
\hline
\end{tabular}


Based on the data acquisition results, it can be concluded that the development of animated video media with a contextual approach has very good validity and is suitable for use as student learning media, especially in the content of science material regarding various styles. In addition, this media can also be used by teachers to make it easier to convey material to students. Suggestions, input, and comments were obtained through the review results of subject matter experts, instructional design experts, learning media experts, individual trials, and small group trials. All suggestions, inputs, and comments become material for revisions that have been followed up for the progress and perfection of the animated video media product with a developed contextual approach. The results of the revised product development of animated video media with a contextual approach are presented in Figure 2.

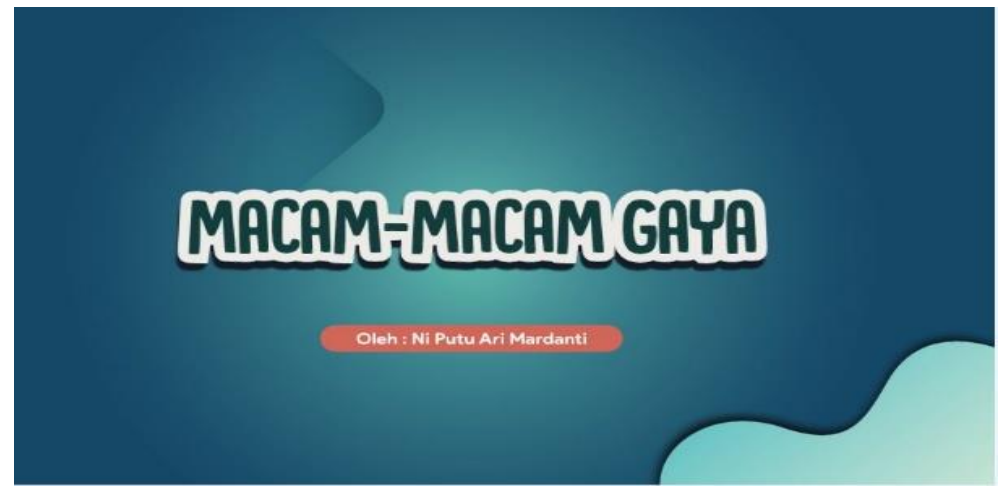

Figure 2. Results of the Revised Opening of the Animated Video that was Developed

\section{Discussion}

The content and content on this animated video media were developed with a very well-qualified contextual learning approach. The essential competencies, indicators, and learning objectives used in the animated video media are by the material in the curriculum so that the learning activities in the animated video media are genuinely able to achieve the learning objectives. Learning materials should be relevant to the achievement of competency standards and essential competencies reflected in the learning objectives (Churri \& Agung, 2013; Hamzah \& Mentari, 2017). The animated video media with a contextual approach that was developed contains material concepts for students to know about various styles and examples that students often encounter through science lessons that support learning objectives. This is in line with the results of previous studies, which state that science learning is very suitable for applying a contextual approach (Kimianti \& Prasetyo, 2019; Mutakinati et al., 2018).

Based on the assessment of the instructional design expert, the animated video media with a contextual approach got a very good qualification assessment. The learning objectives in the media and lesson plans are formulated in the ABCD format (audience, behavior, condition, degree) (Latifa, 2017; Nurtanto et al., 2021). This is by the theory put forward that learning design should be adapted to the process of designing learning objectives, learning experiences, learning resources, and evaluation of learning based on the characteristics of students so that students have the knowledge, attitudes, and skills as a provision for life ((Rozhana \& Harnanik, 2019; Wiyani, 2013). The comments obtained from instructional design experts are very good, where the animated video media can provide meaningful learning activities through examples that are often encountered by students in everyday life and observe videos independently. Learning activities can develop students' skills to actively build their own knowledge and make learning meaningful (Irwansyah et al., 2017; Putri \& 
Arifin, 2017). Other comments besides the voice of the researcher's text, the researcher also uses accompaniment music. Regular arrangement of accompaniment music keeps students motivated to learn (Abendroth \& Richter, 2021; Ismara et al., 2021). For accompaniment music, comments are also given, namely choosing music that is more calming and not too crowded, so that it does not interfere with students' focus in understanding the learning material.

The expert assessment of the animated video media learning media obtained very good qualifications. Four aspects are assessed, namely technical aspects, display aspects, text, and images. Based on expert comments, animated video learning media is very easy to use, only need to click on the link provided, and users are ready to watch animated video media (Maryanti \& Kurniawan, 2018; Noviyanto et al., 2015). By using animated video media, of course, users can repeatedly watch to understand better-animated video material, and this animated video media can be used anywhere at any time repeatedly (Almas \& Krismayani, 2019; E Saripudin et al., 2018). The text aspect got a very good qualification average. Animated video learning media with a contextual approach positively influences student learning outcomes and provides a pleasant atmosphere so that students' attention is focused on videos containing information related to learning materials (Sarnoko, 2016; Dewi, 2013).Based on expert comments, the character images created and selected according to the material and videos integrated with the animated video media have a duration by the characteristics of fourth-grade elementary school students. This makes learning that takes place not tend to be monotonous to take place without obstacles (Audie, 2019; Rubini et al., 2018).

The results of previous studies also stated that animated video media effectively improved student learning outcomes (Febliza \& Okatariani, 2020; Margareta \& Wahyuno, 2014).Other research also states that the results are that animated video media can attract students' attention to study, help clarify the material so that students can learn quickly, and can increase students' cognitive knowledge (Saripudin et al., 2018; Endang Saripudin et al., 2018). The development of animated video media with a contextual approach has implications for the validity of the animated video media products produced and are suitable for use in the learning process. This animated video media development can increase students' interest in learning and help students learn independently according to learning objectives. The implications of using animated video media with a contextual approach as technology-based learning media are supported by existing facilities and infrastructure in schools such as internet access (WiFi), computer/laptop devices, LCDs, projectors, as well as the readiness and skills of teachers and students in accessing animated video media with a contextual approach. On the content of science lessons for grade IV elementary school.

\section{Conclusion}

The results of the assessment by experts of the developed media get excellent qualifications. It can be concluded that this contextual approach to the product development of animated video media is "Very Appropriate" to be used as a learning medium. Suggestions that can be put forward are the need for further development of animated video learning media with a contextual approach and the need to test the product's effectiveness in further research.

\section{References}

Abendroth, J., \& Richter, T. (2021). How to understand what you don't believe: Metacognitive training prevents belief-biases in multiple text comprehension. Learning and Instruction, 71(August 2020), 101394. 
https://doi.org/10.1016/j.learninstruc.2020.101394

Agung, A. A. (2014). Buku Ajar Metodelogi Penelitian Pendidikan. Aditya Media Publishing.

Almas, I., \& Krismayani, I. (2019). Kaji Tindak Penggunaan Meme Dalam Kegiatan Promosi Koleksi Ebook Di Perpustakaan Sma Negeri 3 Semarang. Jurnal Ilmu Perpustakaan, 6(3), 441-450. https://ejournal3.undip.ac.id/index.php/jip/article/view/23176/21201

Alnajdi, S. M. (2018). The Effectiveness of Designing and Using a Practical Interactive Lesson based on ADDIE Model to Enhance Students' Learning Performances in University of Tabuk. Journal of Education and Learning, 7(6), 212. https://doi.org/10.5539/jel.v7n6p212

Amali, L. N., Zees, N., \& Suhada, S. (2020). Motion Graphic Animation Video As Alternative Learning Media. Jambura Journal of Informatics, 2(1). https://doi.org/10.37905/jji.v2i1.4640

Andini, S., Budiyono, \& Fitriana, L. (2018). Developing flipbook multimedia: The achievement of informal deductive thinking level. Journal on Mathematics Education, 9(2), 227-238. https://doi.org/10.22342/jme.9.2.5396.227-238

Audie, N. (2019). Peran Media Pembelajaran Meningkatkan Hasil Belajar Peserta Didik. Prosiding Seminar Nasional Pendidikan FKIP, 2(1), 586-595. https://jurnal.untirta.ac.id/index.php/psnp/article/view/5665

Chou, P.-N. (2013). Students Perceptions Of Success In The Online Graduate-Level Classes: A Self-Directed Learning Perspective. Contemporary Issues in Education Research (CIER), 6(1), 115. https://doi.org/10.19030/cier.v6i1.7610

Churri, M., \& Agung, Y. (2013). Pengembangan Materi Dan Media Pembelajaran Mata Pelajaran Dasar Kompetensi Kejuruan Teknik Audio Video Untuk Smk Negeri 7 Surabaya. Jurnal Pendidikan Teknik Elektro, 2(2), 803-809. https://jurnalmahasiswa.unesa.ac.id/index.php/jurnal-pendidikan-teknikelektro/article/view/4198

Fadhli, M. (2015). Pengembangan Media Pembelajaran Berbasis Video Kelas IV Sekolah Dasar. Jurnal Dimensi Pendidikan Dan Pembelajaran, 3(1), 24-29. https://doi.org/http://dx.doi.org/10.24269/dpp.v3i1.157

Febliza, A., \& Okatariani, O. (2020). The Development of Online Learning Media by Using Moodle for General Chemistry Subject. Journal of Educational Science and Technology (EST), 6(1), 40. https://doi.org/10.26858/est.v6i1.12339

Goldschmidt, K. (2020). The COVID-19 Pandemic: Technology use to Support the Wellbeing of Children. Journal of Pediatric Nursing, 53, 88-90. https://doi.org/10.1016/j.pedn.2020.04.013

Gürsoy, G. (2021). Digital storytelling: Developing 21st century skills in science education. European Journal of Educational Research, 10(1), 97-113. https://doi.org/10.12973/EU-JER.10.1.97

Hamzah, I., \& Mentari, S. (2017). Development of Accounting E-Module to Support the Scientific Approach of Students Grade X Vocational High School. Journal of Accounting and Business Education, 1(1), 78. https://doi.org/10.26675/jabe.v1i1.9751

Hidayatulloh, M. (2019). Developing Electrical Circuits Flipbook Using Flipbuilder. International Journal of Innovation Education and Research, 7(2), 124-134. https://doi.org/10.31686/ijier.vol7.iss2.1331

Hincal, E., \& Alsaadi, S. H. (2021). Stability analysis of fractional order model on corona transmission dynamics. Chaos, Solitons \& Fractals, 143, 110628. https://doi.org/10.1016/j.chaos.2020.110628

Irwansyah, F. S., Lubab, I., Farida, I., \& Ramdhani, M. A. (2017). Designing Interactive Electronic Module in Chemistry Lessons. Journal of Physics: Conference Series, 
895(1). https://doi.org/10.1088/1742-6596/895/1/012009

Ismara, K. I., Suharjono, A., \& Supriadi, D. (2021). Ubiquitous learning in occupational health and safety for vocational education. International Journal of Evaluation and Research in Education, 10(1), 285-292. https://doi.org/10.11591/ijere.v10i1.20823

Jogezai, N. A., Baloch, F. A., Jaffar, M., Shah, T., Khilji, G. K., \& Bashir, S. (2021). Teachers' Attitudes Towards Social Media (SM) Use in Online Learning Amid The COVID-19 Pandemic: The Effects of SM Use by Teachers and Religious Scholars During Physical Distancing. Journal Heliyon, 7(4), 1-9. https://doi.org/10.1016/j.heliyon.2021.e06781

Kadafi, A., Alfaiz, A., Ramli, M., Asri, D. N., \& Finayanti, J. (2021). The impact of islamic counseling intervention towards students' mindfulness and anxiety during the covid-19 pandemic. Islamic Guidance and Counseling Journal, 4(1), 55-66. https://doi.org/10.25217/igcj.v4i1.1018

Kartika, Y., Wahyuni, R., Sinaga, B., \& Rajagukguk, J. (2019). Improving Math Creative Thinking Ability by using Math Adventure Educational Game as an Interactive Media. Journal of Physics: Conference Series, 1179(1), 1-6. https://doi.org/10.1088/17426596/1179/1/012078

Kimianti, F., \& Prasetyo, Z. K. (2019). Pengembangan E-Modul Ipa Berbasis Problem Based Learning Untuk Meningkatkan Literasi Sains Siswa. Kwangsan: Jurnal Teknologi Pendidikan, 7(2), 91. https://doi.org/10.31800/jtp.kw.v7n2.p91--103

Kolta, M. F., \& Ghonimy, M. B. I. (2020). COVID-19 variant radiological findings with high lightening other coronavirus family (SARS and MERS) findings: radiological impact and findings spectrum of corona virus (COVID-19) with comparison to SARS and MERS. Egyptian Journal of Radiology and Nuclear Medicine, 51(1). https://doi.org/10.1186/s43055-020-00262-7

Komala, F. nur. (2016). Pembelajaran IPA Sekolah Dasar. Ediide Indografika.

Kühl, T. (2021). Prerequisite knowledge and time of testing in learning with animations and static pictures: Evidence for the expertise reversal effect. Learning and Instruction, 73. https://doi.org/10.1016/j.learninstruc.2021.101457

Latifa, I. S. (2017). The Analysis of Teachers' Lesson Plan through Behavioral Objectives Theory. Advances in Social Science, Education and Humanities Research (ASSEHR), 82(1), 6-11. https://doi.org/10.2991/conaplin-16.2017.2

Lin, L., \& Li, M. (2018). Optimizing learning from animation: Examining the impact of biofeedback. Learning and Instruction, 55. https://doi.org/10.1016/j.learninstruc.2018.02.005

Linda, Albeta, Masnaini, \& Sulismawati. (2018). The Effect Of Prezy And Exe-Learning Media On Chemical Learning Results. Jurnal Edusains, 10(1). https://doi.org/10.15408/es.v10i1.7204.

Margareta, L., \& Wahyuno, E. (2014). Penggunaan Media Animasi Macromedia Flash Untuk Meningkatkan Kualitas Pembelajaran Ipa Siswa Tunarungu Kelas II SDLB. Jurnal P3Lb, 1(2), 137-139. https://doi.org/10.17977/um029v1i22014p137-139

Marhayani, D. A. (2016). Development of Character Education Based on Local Wisdom in Indegenous People Tengahan Sedangagung. JETL (Journal Of Education, Teaching and Learning), 1(2), 66. https://doi.org/10.26737/jetl.v1i2.40

Maryanti, S., \& Kurniawan, D. T. (2018). Pengembangan Media Pembelajaran Video Animasi Stop Motion Untuk Pembelajaran Biologi Dengan Aplikasi Picpac. Jurnal BIOEDUIN: Program Studi Pendidikan Biologi, 8(1), 26-33. https://doi.org/10.15575/bioeduin.v8i1.2922

Megawati, \& Utami. (2020). English Learning with Powtoon Animation Video. Journal of Education Technology, 4(2), 110. https://doi.org/10.23887/jet.v4i2.25096 
Mpungose, C. B. (2021). Lecturers' reflections on use of Zoom video conferencing technology for e-learning at a South African university in the context of coronavirus. African Identities. https://doi.org/10.1080/14725843.2021.1902268

Mulyantini, N. L. D., Suranata, K., \& Margunayasa, I. G. (2019). Pengaruh Model Pembelajaran Two Stay Two Stray Terhadap Minat Belajar Ipa Siswa Kelas IV SD. MIMBAR PGSD Undiksha, 7(1). https://doi.org/10.23887/jjpgsd.v7i1.17023

Mutakinati, L., Anwari, I., \& Yoshisuke, K. (2018). Analysis of students' critical thinking skill of middle school through stem education project-based learning. Jurnal Pendidikan IPA Indonesia, 7(1), 54-65. https://doi.org/10.15294/jpii.v7i1.10495

Noviyanto, T. S. H., Juanengsih, N., \& Rosyidatun, E. S. (2015). Penggunaan Media Video Animasi Sistem Pernapasan Manusia Untuk Meningkatkan Hasil Belajar Biologi. Edusains, 7(1), 57-63. https://doi.org/10.15408/es.v7i1.1215

Nurtanto, M., Kholifah, N., Masek, A., Sudira, P., \& Samsudin, A. (2021). Crucial problems in arranged the lesson plan of vocational teacher. International Journal of Evaluation and Research in Education (IJERE), 10(1), 345-354. https://doi.org/10.11591/ijere.v10i1.20604

Padli, F., \& Rusdi. (2020). Respon Siswa dalam Pembelajaran Online Selama Pandemi. Social Landscape Journal, 1(3), 1-7. https://ojs.unm.ac.id/SLJ/article/view/14508

Patricia, A. (2020). College Students' Use and Acceptance of Emergency Online Learning Due to COVID-19. International Journal of Educational Research Open, 1(1), 100011. https://doi.org/10.1016/j.ijedro.2020.100011

Putri, M. D., \& Arifin, R. R. M. (2017). Pengaruh Penerapan Model Core Program Studi Pendidikan Guru Sekolah Dasar. Jurnal Khazanah Sekolah Dasar, 5(1), 111-123.

Rahayuningsih, S. (2020). Animation media of animal husbandry thematic science learning to stimulate scientific attitude in early childhood. International Journal of Scientific and Technology Research. https://doi.org/10.23887/jet.v3i1.17959 Article Metrics

Rigianti, H. A. (2020). Kendala Pembelajaran Daring Guru Sekolah Dasar Di Banjarnegara. Elementary School: Jurnal Pendidikan Dan Pembelajaran Ke-SD-An, 7(2). https://doi.org/10.31316/esjurnal.v7i2.768

Rozhana, K. M., \& Harnanik, H. (2019). Lesson Study dengan Metode Discovery Learning dan Problem Based Instruction. Intelegensi: Jurnal Ilmu Pendidikan, 1(2). https://doi.org/10.33366/ilg.v1i2.1355

Rubini, B., Permanasari, A., \& Yuningsih, W. (2018). Learning Multimedia Based on Science Literacy on the Lightning Theme. Jurnal Penelitian Dan Pembelajaran IPA, 4(2), 89-104. https://doi.org/10.30870/jppi.v4i2.3926

Sahu, P. (2020). Closure of Universities Due to Coronavirus Disease 2019 (COVID-19): Impact on Education and Mental Health of Students and Academic Staff. Cureus, 2019(4), 4-9. https://doi.org/10.7759/cureus.7541

Saripudin, E, Sari, I., \& Mukhtar, M. (2018). Using Macro Flash Animation Media on Motion Material to Improve Learning Achievement for Learning Science in Junior High School. , 4 (1),. Journal of Science Research and Learning, 4(1), 68-75. https://doi.org/10.30870/jppi.v4i1.3316

Saripudin, Endang, Sari, I. J., \& Mukhtar, M. (2018). Using Macro Flash Animation Media on Motion Material to Improve Learning Achievement for Learning Science in Junior High School. Jurnal Penelitian Dan Pembelajaran IPA, 4(1), 68-75. https://doi.org/10.30870/jppi.v4i1.3316

Sarnoko, S., Ruminiati, R., \& Setyosari, P. (2016). Penerapan Pendekatan Savi Berbantuan Video Pembelajaran untuk Meningkatkan Aktivitas dan Hasil Belajar IPS Siswa Kelas IV Sdn I Sanan Girimarto Wonogiri. Jurnal Pendidikan: Teori, Penelitian, Dan Pengembangan, 1(7), 1235-1241. https://doi.org/10.17977/jp.v1i7.6524 
Satyawan, V. (2018). The Use Of Animation Video To Teach English At Junior High School Students. Jellt (Journal of English Language and Language Teaching), 2(2), 89-96. https://doi.org/10.36597/jellt.v2i2.3277

Setiawan, Innatesari, D. K., Sabtiawan, W. B., \& Sudarmin, S. (2017). The development of local wisdom-based natural science module to improve science literation of students. Jurnal Pendidikan IPA Indonesia, 6(1), 49-54. https://doi.org/10.15294/jpii.v6i1.9595

Shodiq, I. J., \& Zainiyati, H. S. (2020). Pemanfaatan Media Pembelajaran E-Learning Menggunakan Whastsapp Sebagai Solusi Ditengah Penyebaran Covid-19 Di Mi Nurulhuda Jelu. Al-Insyiroh: Jurnal Studi Keislaman, 6(2), 144-159. https://doi.org/10.35309/alinsyiroh.v6i2.3946

Suartama, I. K. (2016). Materi 4 Evaluasi dan Kriteria Kualitas Multimedia Pembeajaran Oleh: I Kadek Suartama Jurusan Teknologi Pendidikan Universitas Pendidikan Ganesha Tahun 2016. September, 1-18.

Tapingkae, P., Panjaburee, P., Hwang, G.-J., \& Srisawasdi, N. (2020). Effects of a formative assessment-based contextual gaming approach on students' digital citizenship behaviours, learning motivations, and perceptions. Computers \& Education, 159. https://doi.org/10.1016/j.compedu.2020.103998

Trianawati. (2019). Pengaruh Model Discovery Learning Berbantuan Media Animasi Terhadap Kompetensi Pengetahuan IPA Siswa Kelas IV SDN Gugus VI Abiansemal Tahun Ajaran 2018/2019. International Journal of Elementary Education, 4. https://doi.org/10.23887/ijee.v4i1.24337

Van Alten, D. C. D., Phielix, C., Janssen, J., \& Kester, L. (2020). Self-regulated learning support in flipped learning videos enhances learning outcomes. Computers and Education, 158(August), 104000. https://doi.org/10.1016/j.compedu.2020.104000

Widiyasanti, M., Proketen, S. D., \& Yogyakarta, N. (2018). Pengembangan Media Video Animasi Untuk Meningkatkan Motivasi Belajar Dan Karakter Tanggung Jawab Siswa Kelas V. Jurnal Pendidikan Karakter, 8(1), 1-16. https://doi.org/10.21831/jpk.v8i1.21489

Wiyani, N. A. (2013). Desain Pembelajaran Pendidikan. Ar-ruz Media.

$\mathrm{Wu}, \mathrm{T} . \mathrm{T} .$, \& Wu, Y. T. (2020). Applying project-based learning and SCAMPER teaching strategies in engineering education to explore the influence of creativity on cognition, personal motivation, and personality traits. Thinking Skills and Creativity, 35(January), 100631. https://doi.org/10.1016/j.tsc.2020.100631

Yulando, S., Sutopo, S., \& Franklin Chi, T. (2019). Electronic Module Design and Development: An Interactive Learning. American Journal of Educational Research, 7(10), 694-698. https://doi.org/10.12691/education-7-10-4

Yunitasari, R., \& Hanifah, U. (2020). Pengaruh Pembelajaran Daring terhadap Minat Belajar Siswa pada Masa COVID 19. Edukatif: Jurnal Ilmu Pendidikan, 2(3), 232-243. https://doi.org/10.31004/edukatif.v2i3.142 